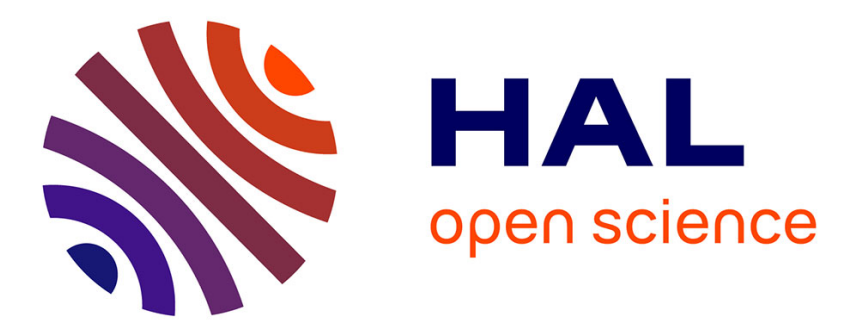

\title{
Several synthetic progestins disrupt the glial cell specific-brain aromatase expression in developing zebra fish
}

Joel Cano-Nicolau, Clementine Garoche, Nathalie Hinfray, Elisabeth Pellegrini, Noureddine Boujrad, Farzad Pakdel, Olivier Kah, François Brion

\section{To cite this version:}

Joel Cano-Nicolau, Clementine Garoche, Nathalie Hinfray, Elisabeth Pellegrini, Noureddine Boujrad, et al.. Several synthetic progestins disrupt the glial cell specific-brain aromatase expression in developing zebra fish. Toxicology and Applied Pharmacology, 2016, 305, pp.12-21. 10.1016/j.taap.2016.05.019 . hal-01366373

\section{HAL Id: hal-01366373}

https://hal-univ-rennes1.archives-ouvertes.fr/hal-01366373

Submitted on 13 Oct 2016

HAL is a multi-disciplinary open access archive for the deposit and dissemination of scientific research documents, whether they are published or not. The documents may come from teaching and research institutions in France or abroad, or from public or private research centers.
L'archive ouverte pluridisciplinaire HAL, est destinée au dépôt et à la diffusion de documents scientifiques de niveau recherche, publiés ou non, émanant des établissements d'enseignement et de recherche français ou étrangers, des laboratoires publics ou privés. 
Several synthetic progestins disrupt the glial cell specific-brain aromatase expression in developing zebra fish

Joel Cano-Nicolau ${ }^{a, *}$, Clémentine Garoche ${ }^{\text {b,* }}$, Nathalie Hinfray ${ }^{\mathrm{b}}$, Elisabeth Pellegrini ${ }^{\mathrm{a}}$, Noureddine Boujrad $^{\mathrm{c}}$, Farzad Pakdel ${ }^{\mathrm{c}}$, Olivier Kah ${ }^{\mathrm{a}, \#}$, François Brion ${ }^{\mathrm{b}, \#}$

*contribute equally to this work.

${ }^{a}$ Team NEED and ${ }^{\mathrm{c}}$ TREK, Institut de recherche en Santé Environnement et Travail (Irset), INSERM U1085, Université de Rennes 1, Campus de Beaulieu, SFR Biosit, 35042 Rennes cedex, France

${ }^{b}$ Unité d'Ecotoxicologie in vitro et in vivo, Institut National de l'Environnement Industriel et des Risques (INERIS), BP 2, 60550, Verneuil-en-Halatte, France

\section{\#Corresponding authors}

Olivier Kah; Phone: +33 (0)2 232367 65; oliver.kah@univ-rennes1.fr

François Brion, Phone: +33(0)3 44556512 ; francois.brion@ineris.fr 


\section{Abstract}

The effects of some progestins on fish reproduction have been recently reported revealing the hazard of this class of steroidal pharmaceuticals. However, their effects at the central nervous system level have been poorly studied until now. Notwithstanding, progesterone, although still widely considered primarily a sex hormone, is an important agent affecting many central nervous system functions. Herein, we investigated the effects of a large set of synthetic ligands of the nuclear progesterone receptor on the glial-specific expression of the zebrafish brain aromatase (cyp19a1b) using zebrafish mechanism-based assays. Progesterone and 24 progestins were first screened on transgenic cyp19a1b-GFP zebrafish embryos. We showed that progesterone, dydrogesterone, drospirenone and all the progesterone-derived progestins had no effect on GFP expression. Conversely, all progestins derived from 19-nortesterone induced GFP in a concentration-dependent manner with $\mathrm{EC}_{50}$ ranging from the low $\mathrm{nM}$ range to hundreds $\mathrm{nM}$. The 19-nortestosterone derived progestins levonorgestrel (LNG) and norethindrone (NET) were further tested in a radial glial cell context using U251-MG cells co-transfected with zebrafish ER subtypes (zfER $\alpha$, zfER $\beta 1$ or zfER $\beta 2$ ) and cyp19a1b promoter linked to luciferase. Progesterone had no effect on luciferase activity while NET and LNG induced luciferase activity that was blocked by ICI 182,780. Zebrafish-ERs competition assays showed that NET and LNG were unable to bind to ERs, suggesting that the effects of these compounds on cyp19a1b require metabolic activation prior to elicit estrogenic activity. Overall, we demonstrate that 19-nortestosterone derived progestins elicit estrogenic activity by inducing cyp19a1b expression in radial glial cells. Given the crucial role of radial glial cells and neuro-estrogens in early development of brain, the consequences of exposure of fish to these compounds require further investigation.

Key words: progestins, brain aromatase, radial glial cells, cyp19a1b-GFP, zebrafish 


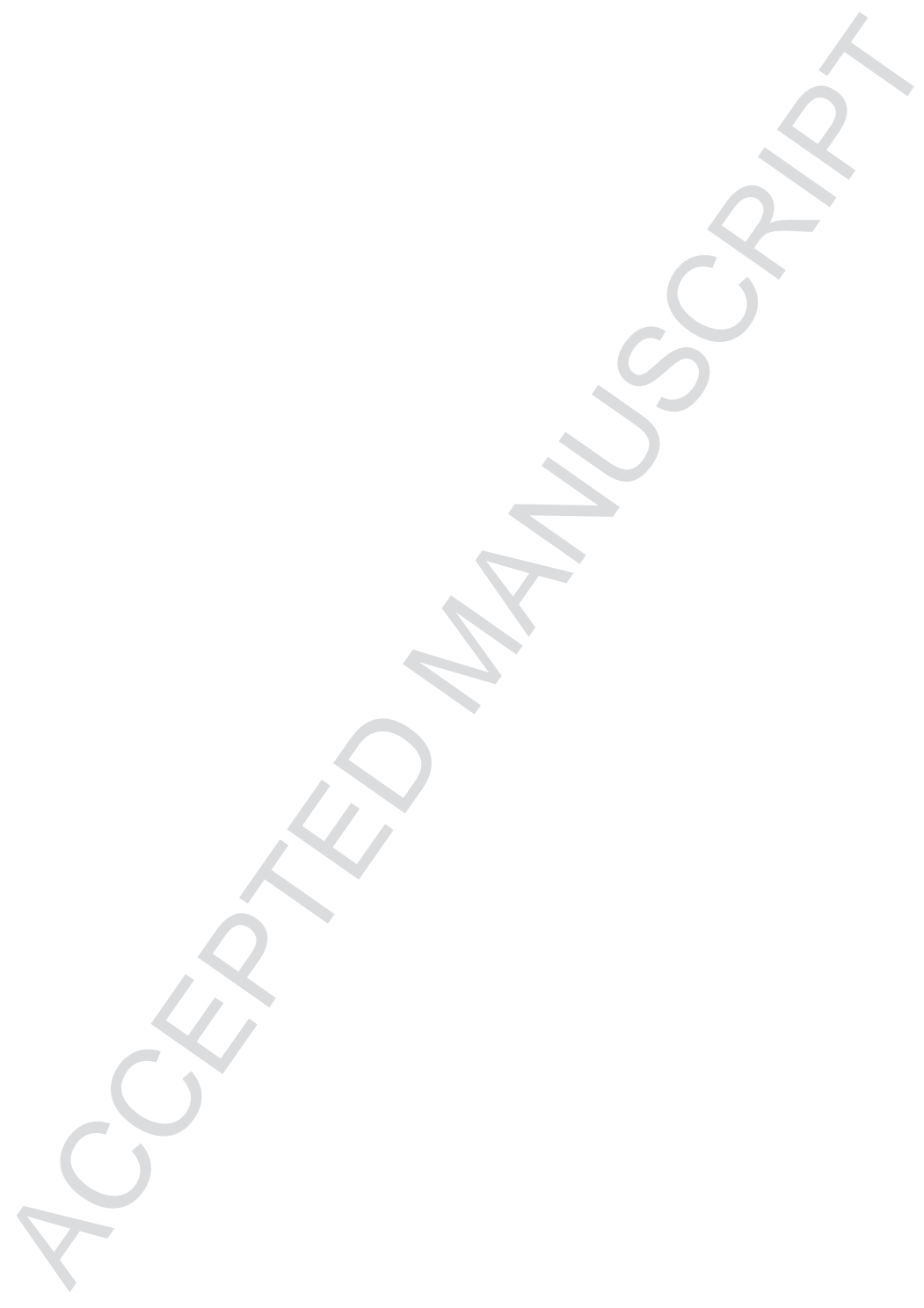




\section{Introduction}

During the past twenty years, numerous studies have examined the effects of estrogenic compounds because these substances were among the first identified as endocrine disrupting compounds (EDCs) responsible for the feminization of wild populations of fish observed worldwide (Sumpter, 2005). Among the most studied xeno-estrogens, a particular attention has been paid to $17 \alpha$-ethinylestradiol (EE2), a potent synthetic steroidal estrogen used as pharmaceuticals in contraceptive pills. From these multiple studies, the mechanism of action and the adverse effects of EE2 on reproductive fitness of aquatic species have been largely documented (e.g., Nash et al., 2004, Kidd et al., 2007, Vosges et al., 2010, Frye et al., 2012; Soffker and Tyler, 2012), which permitted the derivation of Environmental Quality Standard (EQS) for freshwater community (E.C., 2011) and the inscription of EE2 on the watch list of the Water Framework Directive.

In addition to (xeno)-estrogens, there is now evidence of the occurrence of other natural and synthetic steroids released from urban, hospital or industrial waste water treatment plants (WWTPs) effluents (Van der Linden et al., 2008, Chang et al., 2011). In a recent study, the release of hormonally active pharmaceuticals from an industrial WWTP effluent has been associated with altered reproductive physiological functions such as abnormal vitellogenin synthesis, intersex and altered sex-ratio in wild population of gudgeon (Sanchez et al., 2011, Creusot et al., 2014); thereby stressing the need to increase our knowledge of the effects of steroidal pharmaceuticals on aquatic organisms and ecosystems (Creusot et al., 2014, Fent, 2015).

Among steroidal pharmaceuticals, several authors have pointed out the hazard and risks posed by synthetic progestogens on aquatic species (Sumpter 2005, Besse and Garric, 2009, Runnalls et al., 2010, Fent, 2015). Progestagens, also called gestagens or progestins are widely used, not only in the formulation of contraceptive pills, but also in various medical 
applications such as hormone replacement therapy, secondary amenorrhea, dysfunctional uterine bleeding, endometriosis, and in the treatment of several cancers. A large number of progestins that are used as active ingredients of contraceptive pills are used either alone or in combination with estrogens. Part of them are 19-norprogesterone derivatives, often termed pure progestational molecules since they act only through progesterone receptor (Sitruk-Ware, 2008). This progesterone-derived group includes notably medroxy-progesterone, medroxyprogesterone acetate and nestorone. A second group, referred to as testosterone-derivatives (19-Nortestosterone), includes estranes that have a methyl group at the C13 position and gonanes that do not. Among estranes figure ethisterone, norethindrone (NET; also known as norethisterone), norethindrone acetate, ethynodiol-diacetate, tibolone and etonogestrel. Gonanes include compounds such as levonorgestrel, desogestrel, gestodene and norgestimate (Kumar et al., 2015; Sitruk-Ware, 2008). Finally, new molecules have been produced recently, notably drospirenone, a derivative of spironolactone and an aldosterone antagonist (Kumar et al., 2015; Sitruk-Ware, 2008).

The presence of progestins in aquatic environments is much less documented as compared to xeno-estrogens and available data are limited to only few of them (Kumar et al., 2015, Fent, 2015). Furthermore, it is noteworthy that nothing is known about the potential occurrence of their transformation products issued from biotic and/or abiotic process in aquatic environment. Notwithstanding, various studies reported that some progestins can be detected in industrial and urban WWTPs influents and effluents or surface waters at concentration ranging from low nanograms per liter up to $50 \mathrm{ng} / \mathrm{L}$ while in animal farm waste and runoff, their concentrations can reach high levels up to $\mu \mathrm{g} / \mathrm{L}$ (Chang et al., 2011; Labadie and Budzinski, 2005, Creusot et al., 2014, for reviews see Orlando and Ellstad, 2014, Kumar et al., 2015 and Fent, 2015). Importantly, recent research performed on different fish and frog vertebrate models documented that some synthetic progestins disrupted expression of 
hormono-regulated genes and altered reproductive outputs at environmentally relevant concentrations (Bluthgen et al., 2013; Han et al., 2014; Liang et al., 2015; Overturf et al., 2014; Safholm et al., 2015; Zucchi et al., 2014).

Up to now, studies on the environmental effects of progestins in aquatic species are limited to only few progestins. They mainly focused on peripheral organs, such as liver and gonads, in mature fish and pointed out the risk posed by these substances on fish reproduction (Zeilinger et al., 2009, Paulos et al., 2010, Runnalls et al, 2013). Conversely, investigations on the effects of progesterone and progestins at early developmental stages of fish at the central nervous system are scarce. Notwithstanding, significant dysregulation of various genes in the brain of female zebrafish following exposure to drospirenone, a spironolactone derivative, and progesterone have been recently reported (Zucchi et al., 2013; Zucchi et al., 2014, Zhao et al., 2015). However, the underlying mechanisms are still poorly understood. The mechanisms by which progesterone acts in the brain are not fully defined; however in mammals progesterone is known to regulate signals in the brain involving sexually responsive behavior and also to affect gene expression in areas of the brain not involved in sexual behavior (Graham and Clarke, 2011). Nuclear progesterone receptor (nPR) are strongly expressed and exhibit a very large distribution within the brain, suggesting that the central actions of progestagens in fish probably extend beyond reproductive functions possibly including neurogenesis, neuronal plasticity, and/or neuroprotection (Diotel et al., 2011a). Recent data in zebrafish clearly show that nuclear progesterone receptor (nPR) was found to be highly expressed in the preoptic region of the hypothalamus (Hannah et al., 2010). nPR is expressed both neurons and radial glial cells (Diotel et al., 2011b) and the stronger expression of nPR in estrogen-synthesizing radial glial cells suggests a key role of steroids and a probably local action of neurosteroids on radial glial cells activity (Diotel et al., 2011b).

In zebrafish, nuclear progesterone receptor (nPR) was found to be highly expressed in the preoptic region of the hypothalamus (Hannah et al., 2010), but the effects of progestins through nPR would be minimal given that several progestins seems unable to activate nPR in 
different fish species (Bain et al., 2015, Ellestad et al., 2014). Conversely, they may act through other pathways as they can interfere with multiple nuclear steroid receptors (e.g., androgen, glucocorticoid, mineralocorticoid and estrogen receptors) potentially inducing multiple hormonal activities (Besse and Garric, 2009, Fent, 2015).

In light of this context, this work aimed to assess the effects of progesterone (P4) and a large set of (anti-)progestins on the brain aromatase in zebrafish embryos, a commonly recognized alternative model in (eco)toxicology (Strahle et al., 2012). Brain aromatase, encoded by the cyp19a1b gene, is the enzyme responsible for the biosynthesis of neuroestrogens. We have previously shown that cyp19a1b expression is strongly stimulated by estrogens and that the estrogen-dependent cyp19a1b up-regulation requires the presence of functional estrogen receptors (ERs) and a glial X factor (Menuet et al., 2005, Le Page et al., 2008). Furthermore, we showed that expression of brain aromatase is restricted to radial glial cells of embryonic and adult zebrafish (Menuet et al., 2005; Tong et al., 2009).

In the present work, the concentration-dependent effects of P4 and 24 (anti-)progestins on brain aromatase were quantified using the EASZY assay, a mechanism-based assay in $\operatorname{tg}($ cyp19a1b-GFP) zebrafish embryos, that detects substances acting through estrogen receptors (Brion et al., 2012). Among the progestins tested, the molecular mode of action of two of them, levonorgestrel (LNG) and norethindrone (NET) were then further studied in the ER negative glial cell line U251-MG co-transfected with estrogen receptor zfER $\alpha$, zfER $\beta 1$, or zfERß2 (Menuet et al., 2002) together with a reporter luciferase gene linked to 500pb of the proximal promoter of zf cyp19a1b (Le Page et al., 2006).

Herein, we reported that all the 19 nor-testosterone derivatives induced an early developmental effect in the developing brain of zebrafish by targeting radial glial cells and inducing brain aromatase through an ER-dependent mechanism at concentrations ranging from the low $\mathrm{nM}$ to hundreds $\mathrm{nM}$. The estrogenic effect likely required metabolic activation 
of the parent compounds into estrogenic metabolites as they do not bind to zfERs. The (eco)toxicological relevance of this findings is discussed as regards the potential impact of progestins on fish on (neuro)-development. 


\section{Material and Methods}

\subsection{Chemicals}

17ß-estradiol (E2), 17 $\alpha$-ethinylestradiol (EE2), testosterone (T), pregnenolone (P5), progesterone (P4), dydrogesterone (DYD), medroxyprogesterone (MEP), medroxyprogesterone acetate (MPA), megestrol acetate (MGA), chlormadinone acetate (CMA), cyproterone acetate (CPA), promegestone (R5020), nestorone (NES), nomegestrol acetate (NGA), ethisterone (ETH), ethynodiol diacetate (EDA), lynestrenol (LYN), norethindrone acetate (NEA), norethindrone (NET), tibolone (TIB), desogestrel (DSG), etonogestrel (ENG), gestodene (GES), levonorgestrel (LNG), norgestimate (NTE), norgestrel (NGL), drospirenone (DRO), mifepristone (RU486), finasteride (FIN) and trislostane (TRI) were obtained from Sigma-Aldrich Chemical Co. (St.Louis, MO). Gestonorone (GRN) was obtained from Toronto Research Chemicals (Toronto, Canada). ICI 182-780 (ICI) was purchased from Tocris (USA). Stock solutions of chemicals were prepared in dimethyl sulfoxide (DMSO) and stored at $-20^{\circ} \mathrm{C}$. Fresh dilutions of test chemicals were prepared before each experiment.

\subsection{Animals and Exposures to EDCs: EASZY assay}

Fertilized $\operatorname{tg}($ cyp19a1b-GFP) zebrafish eggs were exposed to chemicals or to solvent control (DMSO; $0.01 \% \mathrm{v} / \mathrm{v})$. Each experimental group consisted of 20 embryos exposed in 25 $\mathrm{ml}$ of water. Embryos were kept in an incubator at $28^{\circ} \mathrm{C}$, under semi-static conditions. Exposures were performed from 0 to 4 days post-fertilization (dpf). At the end of the exposure period, 4-dpf old zebrafish were processed for fluorescence measurement by in vivo imaging using wide-field fluorescence microscopy. Each chemical was tested at least twice.

\subsection{In Vivo Imaging: Wide-field Fluorescence Microscopy}

Live $\operatorname{tg}($ cyp19a1b-GFP) embryos were observed in dorsal view and each was 
photographed using a Zeiss AxioImager.Z1 fluorescence microscope equipped with a AxioCam Mrm camera (Zeiss GmbH, Göttingen, Germany). Only the head was photographed using a X10 objective, with a 134 ms exposure time at maximal intensity. Photographs were analyzed using the Zen software and fluorescence quantification was realized using the ImageJ software. For each picture, the integrated density was measured, i.e. the sum of the gray-values of all the pixels within the region of interest. A gray-value of 290 was defined as background value.

\subsection{Plasmid constructs.}

The zfER- $\alpha$, zfER- $\beta 1$, and zfER- $\beta 2$ expression vectors correspond to TOPO-pcDNA3 expression vector (Invitrogen, San Diego, CA, USA), containing the coding regions of each cDNA receptor sequence as previously described (Menuet et al., 2002). The cyp19a1bluciferase reporter gene consists of $500 \mathrm{pb}$ of the proximal promoter region of zebrafish cyp19a1b containing an estrogen response element (ERE), coupled to the luciferase reporter gene, as previously described (Menuet et al., 2005).

\subsection{In vitro transcription/translation of $\mathrm{zfERs}$}

To synthesize zfER proteins, we performed an in vitro translation reaction using the TNT Quick Coupled Transcription/Translation Systems kit (Promega) and adding $1 \mu \mathrm{g}$ of each ER expression vector. The transcend Non-Radioactive Translation Detection Systems kit (Promega, Madison, Wisconsin, USA) was used to visualize all three receptors.

\subsection{Cell culture and transfection}

Cell culture and transfection were performed according to Le page et al., (2006). In brief, U251-MG cells were maintained at $37^{\circ} \mathrm{C}$ in $5 \% \mathrm{CO} 2$ atmosphere in phenol red-free Dulbecco's Modified Eagle's Medium (DMEM) supplemented with 2,5\% non-steroid fetal calf serum (Biowest, Nuaillé, France). The medium was also supplemented with $1 \mathrm{mM}$ Na- 
Pyruvate (Life Technologies, Saint Aubin, France), 4nM L-glutamine, and the antibiotics penicillin $(20 \mathrm{U} / \mathrm{mL})$, streptomycin $(20 \mu \mathrm{g} / \mathrm{mL})$, and amphotericin $\mathrm{B}(50 \mathrm{ng} / \mathrm{mL})(\mathrm{Gibco}$, Carlsbad, CA, USA). For transfection, cells were plated in 24-well plates at a density of $0.25 \times 10^{5}$ cells $/ \mathrm{ml}$. In each well, $25 \mathrm{ng}$ of expression vector, $25 \mathrm{ng}$ of cytomegalovirus- $\beta$ galactosidase plasmid and $150 \mathrm{ng}$ of luciferase reporter construct were transfected using jetPEI transfection reagent (Polyplus, Transfection, Illkirch, France). After one night, medium was replaced with fresh DMEM with xenoestrogen or vehicle. Luciferase activity was measured 24 hours later, using the luciferase assay system (Promega, Madison, WI, USA). $\beta$ galactosidase activity was used to normalize transfections efficiency in all experiments. Each experiment was performed in triplicate.

\section{7. $\quad$ Estradiol receptor binding studies}

The binding properties of LNG and NET to all three zfERs were monitored by radioactive competition assay (Blair et al., 2000). Cytosol aliquots of zfERs were incubated with $10^{-9} \mathrm{M}$ $\left[{ }^{3} \mathrm{H}\right]-\mathrm{E} 2$ at $4{ }^{\circ} \mathrm{C}$ overnight, in the absence or presence of increasing concentrations of radioinert E2 $\left(10^{-11} \mathrm{M} ; 10^{-10} \mathrm{M}, 10^{-9} \mathrm{M}, 10^{-8} \mathrm{M}, 10^{-7} \mathrm{M}\right)$ and both synthetic progestagens LNG and NET $\left(10^{-11} \mathrm{M} ; 10^{-10} \mathrm{M}, 10^{-9} \mathrm{M}, 10^{-8} \mathrm{M}, 10^{-7} \mathrm{M}, 10^{-6} \mathrm{M}\right)$. The relative binding affinities of the compounds for cytosolic zfER were evaluated by their capability to displace $\left[{ }^{3} \mathrm{H}\right]$-E2 from the zfER binding site. The results were expressed as a percentage of displaced $\left[{ }^{3} \mathrm{H}\right]$-E2 binding. The $10^{-7} \mathrm{M}$ E2 contained a 100 -fold excess of radioinert E2 compared to $\left[{ }^{3} \mathrm{H}\right]$-E2 and thus represents the non-specific binding (Blair et al., 2000).

\subsection{Data Analysis}

Chemicals were tested in at least two independent experiments. Data are expressed as a mean fold induction above solvent control $+/-$ standard error of the mean (SEM). 
Concentration-response curves were modeled using the Regtox 7.0.6 Microsoft Excel TM macro (http://www.normalesup.org/ vindimian/fr_index.html), which uses the Hill equation model and allows calculation of $\mathrm{EC}_{50}$. For a given chemical, $\mathrm{EC}_{50}$ was defined as the concentration inducing 50\% of its maximal effect. Data were first checked for normality using Shapiro-Wilk test, then homogeneity of variances was checked using Fligner-Killeen test. An ANOVA one-way test was used for the analysis of the variance, followed by Tukey HSD post-hoc test. When the data were not normal, they were log-transformed. If the data were still not normal data or the variances non-homogenous, Kruskal-Wallis test was used for the analysis of the variance. All analyses were conducted in R (R development Core Team, 2015). 


\section{Results}

\subsection{Effects of progestins on GFP expression in transgenic cyp19a1b-GFP zebrafish embryos (EASZY assay).}

The concentration-dependent-responses of E2, T, P5 as well as P4 and synthetic nPR agonists and antagonist ligands were first established on tg cyp19a1b-GFP zebrafish embryos assay. For each compound the effects were quantified using in vivo imaging and ECs were derived for active compounds (Table 2, Figure S1). As expected, E2 and T induced GFP expression in a concentration-dependent manner. P5 also significantly up-regulated GFP expression while P4 and its isomer DYD, as well as progestins structurally related to progesterone showed no effect on GFP expression in the radial glial cells of zebrafish (figure S1). This includes the compounds derived from 17 $\alpha$-hydroxyprogesterone (MEP, MPA, MGA, CMA and CPA), the compounds derived from 19-norprogesterone (R5020, NES and NGA) and GRN derived from 17 $\alpha$-hydroxy-19-norprogesterone (Table 2, Figure S1). Conversely, the progestins derived from 19-nortestosterone ETH, EDA, LYN, NEA, NET, TIB, ENG, GES, LNG, NTE, and NGL induced the expression of GFP in the radial glial cells of zebrafish (Figure 1). Each of these compounds induced GFP in a concentration-dependent manner (figure $\mathrm{S} 1$ ), with $\mathrm{EC}_{50}$ calculated between $0.3 \mathrm{nM}$ for the most active compound (TIB) and $222 \mathrm{nM}$ for the less active (GES) (Table 2). The 19-nortestosterone derived progestin DSG and the nPR antagonist RU486 showed a weak estrogenic effect at the highest tested concentration $\left(10^{-6} \mathrm{M}\right)$ (Figure 1, Figure S1). The progestin derived from spironolactone DRO did not induce GFP expression compared to the solvent control.

\subsection{Mode of action of LNG and NET using U251-MG cell lines}

In order to get further insights on the mechanisms underlying those estrogenic effects, we used an in vitro assay previously developed in our laboratory using the ER negative human astrocyte cell line U251-MG (Le Page et al., 2006; Menuet et al., 2005). To study the 
respective role of each ZfER, cells were co-transfected with one of the three subtypes (zfER $\alpha$, zfER $\beta 1$, or zfER $\beta 2$ ) and the luciferase gene under the control of cyp19a1b promoter. The cells were treated for 24 hours with the different compounds. Figure 2 shows that, as expected, E2 $\left(10^{-8} \mathrm{M}\right)$ used as a positive control caused a strong induction with the three receptors. As documented before (Le Page et al., 2006), the fold induction was much stronger with zfER $\alpha$ (25 to 35 times) than with zfER $\beta 1$ (10 to 15$)$, or zfER $\beta 2$ (15 to 20). In contrast, $\mathrm{P} 4$ at concentrations of $10^{-9} \mathrm{M}$ to $10^{-6} \mathrm{M}$ had absolutely no effect with zfERs (Figure 2A-F), confirming the results obtained in vivo. Figure (3A-C) shows that NET causes luciferase induction at $10^{-7} \mathrm{M}$ and $10^{-6} \mathrm{M}$, however at the concentration of $10^{-7} \mathrm{M}$, the effect was significant only with zfER $\beta 2$. In the context of the U251-MG cells, these effects were completely blocked by ICI $182,780\left(10^{-6} \mathrm{M}\right)$, which had no effect by itself. It should be noted that the maximal induction caused by NET on zfER $\beta 2$ is within the same range than that observed with zfER $\alpha$ (around 12 times). LNG also increased luciferase expression but only at $10^{-6} \mathrm{M}$ and the maximal induction was much lower (around 2-3 times) than with NET (Figures 4A-C). In the same way these effects were fully blocked by ICI 182,780 at $10^{-6} \mathrm{M}$ (Figures 4D-F).

\subsection{Binding activity of NET and LNG on the three zfERs}

In order to investigate whether the estrogenic activities of NET and LNG in vivo and in vitro were due to a direct activation of zfER, we monitored the binding properties of these compounds to the three zfER expressed in vitro. Figure 5A-C shows that, in contrast to E2 that started displacing $\left[{ }^{3} \mathrm{H}\right]-\mathrm{E} 2$ binding at $10^{-10} \mathrm{M}$ (zfER $\left.\beta 2\right)$ or $10^{-9} \mathrm{M}(\mathrm{zfER} \alpha$ and $\mathrm{zfER} \beta 1)$, both progestins NET and LNG did not yield any displacement at a concentration of $10^{-6} \mathrm{M}$. Only concentrations of $10^{-5} \mathrm{M}$ or $10^{-4} \mathrm{M}$ were effective in reducing $\left[{ }^{3} \mathrm{H}\right]-\mathrm{E} 2$ (data not shown). 


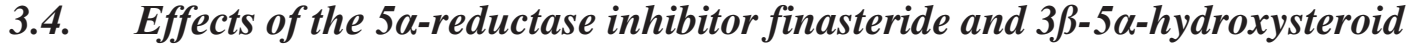 dehydrogenase inhibitor trilostan on the estrogenic effects of LNG and NET}

Because progestins showed no binding to zfERs at relevant concentrations that exhibited in vivo and in vivo estrogenic activity, we investigated whether the estrogenic effects could be due to metabolization of these compounds by $5 \alpha$-reductase and/or $3 \beta-5 \alpha$-hydroxysteroid dehydrogenase as shown in mammals. Exposure of zebrafish to finasteride and trilostane alone had no effect on cyp19a1b expression neither in vivo nor in vitro (figures S2-S5). Finasteride and trilostane at a concentration of $10^{-6} \mathrm{M}$ failed to prevent the GFP induction caused by NET and LNG in $\operatorname{tg}($ cyp19a1b-GFP) embryos (figures S2-S4 respectively). Similarly, finasteride and trilostane had no or very little effect on LNG- and NET-induced cyp19a1b-luciferase in the U251-MG cells, (Figure S3-S5). Surprisingly, finasteride caused a significant reduction of the NET luciferase induction, but only with the zfERß1. 


\section{Discussion}

\subsection{All 19-nortestosterone derived progestins up-regulate brain aromatase in an}

\section{ER-dependent manner}

We used the EASZY assay as a screening tool to establish concentration-response curves for 4 natural steroids and 24 (anti-)progestins on cyp19a1b expression, hence covering all chemical classes to which progestins belong to. Among all the tested compounds, $17 \beta$ estradiol (E2) was, as expected, the most active steroid on brain aromatase while testosterone exhibited a weaker estrogenic activity that likely results from its active aromatization into estradiol (Mouriec et al., 2009, Brion et al., 2012). Pregnenolone, a precursor of steroid hormones that has been already detected in aquatic environment (Creusot et al., 2014), showed an estrogenic activity which could reflect either its capacity to activate ER as shown in human cells (Lemmen et al., 2002, Creusot et al., 2014) or its biotransformation by steroidogenic enzymes that are expressed in the brain of zebrafish (Diotel et al., 2011c). Interestingly, the in vivo relative estrogenic potency of pregnenolone we report herein is much higher than previously reported in vitro in human cells (Lemmen et al., 2002, Creusot et al., 2014).

Progesterone, the natural ligand of the nPR, exhibited no effect on cyp19a1b in radial glial cell context neither in vivo nor in vitro in U-251 MG cells (Figure S1, Figure 2), thus confirming the lack of transactivation activity of $\mathrm{P} 4$ in $\mathrm{CHO}$ cells co-transfected with ERETK-Luc and zebrafish ER subtypes (Menuet et al., 2002). Similarly, we found that all the progesterone-derived progestins do not exhibit any estrogenic activity similar to what is known in mammals (Botella et al., 1995). Interestingly, the anti-progestin mifepristone significantly induced GFP expression in embryos in an ER-dependent manner but only at high concentrations. 
In contrast to progesterone-derived progestins, our data show that all testosteronederived progestins are able to affect cyp19a1b-GFP expression in vivo in a concentrationdependent manner. We thus confirmed the effect of LNG and NET on brain aromatase (Brion et al., 2012) and extended these finding to 11 other progestins (ETH, EDA, LYN, NEA, TIB, DSG, ENG, GES, NTE, NGL, RU486) among which 9 had never been studied before in zebrafish embryos.

All active compounds induced full concentration-dependent responses with maximal inductions of GFP that often exceeded those measured in zebrafish exposed to E2 or EE2 (Figure S1, Brion et al., 2012). Overall, estranes were the most active compounds as compared to gonanes with the exception of ENG which exhibited a similar activity as ETH. All were active at concentrations in the sub nM range to hundreds $\mathrm{nM}$. It is noteworthy that the estrogenic potency of tibolone was more than 5-fold higher than that of E2, while other progestins such as norethindrone acetate and norethindrone had estrogenic activities much closer to that of E2, highlighting the strong estrogenic activity of these compounds in the brain of zebrafish embryos.

\subsection{LNG and NET exhibit estrogenic effects in the U251-MG cell line transfected with ZfERs but do not bind to ZfERs}

In order to get further insights into the mechanisms underlying the estrogenic effects of the 19-nortestosterone derivatives, we focused on NET and LNG. Our in vivo data using the EASZY assay showed that NET is very active with an $\mathrm{EC}_{50}$ in the $\mathrm{nM}$ range, while LNG is less potent. This is confirmed by the in vitro assay using the U-251 MG cells indicating that both NET and LNG can induce transactivation of the cyp19a1b-luciferase reporter in the presence of one of the three zefrafish ER. However, with the three zebrafish ER, NET is much more efficient than LNG, eliciting a response with a concentration of $10^{-7} \mathrm{M}$ and a maximal 
fold induction 3 to 5 times higher. Thus, these in vitro data confirms the data obtained in vivo. In all cases, ICI 182,780 blocked these effects, indicating that they are ER-mediated. However, binding assays showed that NET and LNG were not able to displace $\left[{ }^{3} \mathrm{H}\right]-\mathrm{E} 2$ binding on the three receptors, except only at very high concentrations (superior to $10^{-6} \mathrm{M}$ ). Interestingly, although NET is about ten times more efficient than LNG in vivo and in U-251 MG cells, it exhibits a much lower capacity than LNG in displacing $\left[{ }^{3} \mathrm{H}\right]-\mathrm{E} 2$. This strongly suggests that the in vitro and in vivo effects of NET and LNG in the U-251 MG and tg cyp19a1b-GFP on cyp19a1b expression do not involve binding of the parent compounds to zfERs but their estrogenic effects are likely to be due to metabolization into estrogenic metabolites.

In mammalian target tissues, in particular in bones, NET was shown to be biotransformed by $5 \alpha$-reductase into $5 \alpha$-NET, which can be further metabolized in $3 \alpha, 5 \alpha-$ tetrahydro-NET $(3 \alpha, 5 \alpha-\mathrm{NET})$ and $3 \beta, 5 \alpha-$ tetrahydro-NET $(3 \beta, 5 \alpha-\mathrm{NET})$ by $3 \alpha-5 \alpha-$ hydroxysteroid and 3ß-5 $\alpha$-hydroxysteroid deshydrogenases, respectively (Enriquez et al., 2007; Garcia-Becerra et al., 2006; Lemus et al., 2009). In rat cultured osteoblastic cells, these reduced derivatives of NET induced significant effects on rat osteoblast proliferation and differentiation, similar to estradiol (Lemus et al., 2009). However, these effects were completely blocked by finasteride, a type II and III $5 \alpha$-reductase inhibitor. Finasteride has a molecular weight of $372 \mathrm{~g} / \mathrm{mol}$, is lipophilic (Azeem et al., 2009) and has recently been shown to be active in teleost fishes (Lee et al., 2015). Because 5 $\alpha$-reductase is abundant in the brain of fish (Diotel et al., 2011a; Pasmanik and Callard, 1988), we attempted to block the effects of NET or LNG with this compound. In vivo, finasteride alone had no visible effect on the development of embryos. In combination with estradiol, finasteride had no effect on the estradiol-induced GFP expression, and in association with NET or LNG, the $5 \alpha$-reductase inhibitor did not affect at all the estrogenic activity of these two progestagens. Because it is 
possible that finasteride, despite its small size and lipophilic nature, did not penetrate into the embryos, we repeated this experiment in vitro in the U-251 MG cells, since 5 $\alpha$-reductase is known for being expressed in astrocytes (Bruzzone et al., 2010; Kiyokage et al., 2005). Finasteride did not affect the luciferase induction caused by NET or LNG in these cells. Trilostane, an inhibitor of 3ß-5 $\alpha$-hydroxysteroid deshydrogenases that has been demonstrated to be active in medaka fish (Sun et al., 2014) did not affect either the in vivo or the in vitro estrogenic activities of NET or LNG. The underlying metabolic pathways through which these compounds are metabolized into estrogenic metabolites remain to be identified in fish.

\section{3. (Eco)toxicological relevance of progestin-induced cyp19a1b expression during embryogenesis.}

To our knowledge, our study is the first to provide an extensive characterization of the effects of progestins on an estrogen-dependent gene in brain of fish and to demonstrate that more than half of the nPR ligands tested (i.e., 13 out of 25) act in a similar way to $17 \beta$ estradiol. Even though progestin concentrations used to trigger induction of aromatase in the short-term EASZY assay are higher than those found in effluent and surface waters, it should be stressed that due to the hydrophobic nature of progestins with log Kows between 3.1 and 5.4 they tend to accumulate in aquatic organisms (Kumar et al., 2015, Fent, 2015). Furthermore wild fish are very likely exposed to mixtures of progestins together with other EDCs, some of which act as estrogens. Investigating the combined effects of progestins with estrogens on cyp19a1b expression thus appears relevant to further assess the hazard of these environmental contaminants (Hinfray et al., under revision).

Previous studies reported effects of P4 and some of the (anti-)progestins tested in this study (i.e., DYD, MPA, NET, LNG, NGL, DRO and RU486) on the transcriptional activity of multiple genes (e.g., steroid hormone receptors, steroidogenic enzymes or circadian rhythm 
genes) during zebrafish embryogenesis that may affect brain and sex development (Zucchi et al., 2012, Liang et al., 2015, Zhao et al., 2015, for a review see Fent et al., 2015 and Kumar et al., 2015). Herein, the effects of 17 progestins on zebrafish embryos were newly assessed. By means of fluorescence imaging in progestins exposed-transgenic cyp19a1b-GFP embryos, we further describe the negative effect of 13 synthetic (anti)progestins on the brain of fish by demonstrating their capacity to target radial glial cells and to induce brain aromatase expression in an ER-dependent manner. The spatio-temporal expression of ERs subtypes have been well-described during zebrafish embryogenesis revealing that ER $\beta$ subtypes and brain aromatase are functionally co-expressed very early during brain development (Mouriec et al., 2009). Our data thus demonstrate that several synthetic progestins have the potential to interfere with ER signaling in developing fish. It is important to recall here that progestins are known to act on multiple nuclear receptors and it would therefore be advisable to further document their potential effects on other NR-regulated pathways in developing brain of fish. Among those, activation of fathead minnow (Pimephales promelas) AR by progestins has been recently pointed out (Ellestad et al., 2014). However, no information is currently available in zebrafish. Furthermore, as compared to ER, much less information is available on AR signaling pathway during embryogenesis, even though AR was found to be expressed in discrete regions of the brain (Gorelick et al., 2008) and AR-responsive genes have recently been described (Fetter et al., 2015).

An important outcome of this study relies on the fact that progestins act on radial glial cells that play a crucial role in neurogenesis and brain repair as they are brain stem cells in developing and adult fish (Lam et al., 2009; Pellegrini et al., 2007; Zupanc, 2008) giving birth to neurons (Diotel et al., 2013; Pellegrini et al., 2007). It is known that estrogens in adult zebrafish and larvae affect neurogenesis by modulating the neurogenic activity of radial glial cells (Diotel et al., 2013). Consequences of early exposure to environmental progestins on 
brain development are unknown, but given the estrogenic activity that we report for the majority of progestins studied, it would therefore be advisable to further document their effects on cell proliferation, survival and migration in brain.

\section{Conclusion}

This study provides an extensive toxicological characterization of a large number of currently used (anti-)progestin pharmaceuticals as regard their estrogenic activity. We demonstrate that a majority of them have the capacity to target radial glial cells and to induce brain aromatase expression in zebrafish embryos in an ER-dependent manner. This work thus provides new information on the effects of progestins in fish at the brain level that deserve further study.

\section{Acknowledgements.}

The authors wish to express their sincere thanks to the anonymous reviewers for their positive and constructive comments. This research was supported by the ANR PROOFS "Occurrences and effects of environmental ligands of progesterone receptor on fish reproduction and neuro-development" (ANR-13-CESA-0006-03). Clémentine Garoche was supported by a doctoral fellowship from the ANR PROOFS and the French Ministry of Ecology (P190 “Axe de Recherche Ecotoxicologie”). The authors acknowledge the staff of the zebrafish Biosit facility (LPGP, INRA, Rennes) and Benjamin Piccini (ECOT unit, INERIS, Verneuil-en-Halatte) for his help in performing zebrafish exposures. 


\section{References}

Azeem, A., Khan, Z.I., Aqil, M., Ahmad, F.J., Khar, R.K., Talegaonkar, S., 2009. Microemulsions as a surrogate carrier for dermal drug delivery. Life Sci., 35, 525-547.

Bain, P.A., Kumar, A., Ogino, Y., Iguchi, T., 2015. Nortestosterone-derived synthetic progestogens do not activate the progestogen receptor of Murray-Darling rainbowfish (Melanotaenia fluviatilis) but are potent agonists of androgen receptors alpha and beta. Aquat. Toxicol 163, 97-101.

Besse JP, Garric J. 2009 Progestagens for human use, exposure and hazard assessment for the aquatic environment. Environ. Pollut..;157(12):3485-94.

Blair, R.M., Fang, H., Branham, W.S., Hass, B.S., Dial, S.L., Moland, C.L., Tong, W., Shi, L., Perkins, R., Sheehan, D.M., 2000. The estrogen receptor relative binding affinities of 188 natural and xenochemicals: structural diversity of ligands. Toxicol. Sci., 54, 138-153.

Bluthgen, N., Castiglioni, S., Sumpter, J.P., Fent, K., 2013. Effects of low concentrations of the antiprogestin mifepristone (RU486) in adults and embryos of zebrafish (Danio rerio): 1. Reproductive and early developmental effects. Aquat. Toxicol 144-145, 83-95.

Botella, J., Duranti, E., Viader, V., Duc, I., Delansorne, R., Paris, J. (1995). Lack of estrogenic potential of progesterone- or 19-nor-progesterone-derived progestins as opposed to testosterone or 19-nor-testosterone derivatives on endometrial Ishikawa cells.J Steroid Biochem Mol Biol.;55(1):77-84

Brion, F., Le Page, Y., Piccini, B., Cardoso, O., Tong, S.K., Chung, B.C., Kah, O., 2012.

Screening estrogenic activities of chemicals or mixtures in vivo using transgenic (cyp19a1bGFP) zebrafish embryos. PloS one 7, e36069.

Bruzzone, F., Do Rego, J.L., Luu-The, V., Pelletier, G., Vallarino, M., Vaudry, H., 2010. Immunohistochemical localization and biological activity of 3beta-hydroxysteroid dehydrogenase and 5alpha-reductase in the brain of the frog, Rana esculenta, during development. J. Chem Neuroanat., 39, 35-50.

Chang, H., Wan, Y., Wu, S., Fan, Z., Hu, J., 2011. Occurrence of androgens and progestogens in wastewater treatment plants and receiving river waters: comparison to estrogens. Water Res. 45, 732-740. 
Creusot, N., Aït-Aïssa, S., Tapie, N., Pardon, P., Brion, F., Sanchez, W., Thybaud, E., Porcher, JM., Budzinski, H. 2014. Identification of synthetic steroids in river water downstream from pharmaceutical manufacture discharges based on a bioanalytical approach and passive sampling. Environ Sci Technol. 2 1;48(7):3649-57.

Diotel, N., Do Rego, J.L., Anglade, I., Vaillant, C., Pellegrini, E., Gueguen, M.M., Mironov, S., Vaudry, H., Kah, O., 2011a The brain of teleost fish, a source, and a target of sexual steroids. Front. Neurosci., http://dx.doi.org/10.3389/fnins.2011.00137

Diotel, N., Servili, A., Gueguen, M-M., Mironov, S., Pellegrini, E., Vaillant, C., Zhu, Y., Kah, O., and Anglade, I. 2011b. Nuclear progesterone receptors are up-regulated by estrogens in neurons and radial glial progenitors in the brain of zebrafish. PLoS ONE 6:11. e28375. doi:10.1371/journal.pone.0028375

Diotel, N., Do Rego, J.L., Anglade, I., Vaillant, C., Pellegrini, E., Gueguen, M.M., Mironov, S., Vaudry, H., Kah, O., 2011c. Activity and expression of steroidogenic enzymes in the brain of adult zebrafish. Eur. J. Neurosci. 34, 45-56.

Diotel, N., Vaillant, C., Gabbero, C., Mironov, S., Fostier, A., Gueguen, M.M., Anglade, I., Kah, O., Pellegrini, E., 2013. Effects of estradiol in adult neurogenesis and brain repair in zebrafish. Horm. Behav., 63, 193-207.

E.C. (2011). Ethinylestradiol EQS dossier prepared by the Sub-Group on Review of the Priority Substances List under Working Group E on Chemical Aspects in the context of the Common Implementation Strategy for the Water Framework Directive. pp. 36.

Ellestad, L.E., Cardon, M., Chambers, I.G., Farmer, J.L., Hartig, P., Stevens, K., Villeneuve, D.L., Wilson, V., Orlando, E.F., 2014. Environmental gestagens activate fathead minnow (Pimephales promelas) nuclear progesterone and androgen receptors in vitro. Environ Sci. Technol., 48, 8179-8187.

Enriquez, J., Lemus, A.E., Chimal-Monroy, J., Arzate, H., Garcia, G.A., Herrero, B., Larrea, F., Perez-Palacios, G., 2007. The effects of synthetic 19-norprogestins on osteoblastic cell function are mediated by their non-phenolic reduced metabolites. J. Endocrinol., 193, 493504.

Fent, K. 2015 Progestins as endocrine disrupters in aquatic ecosystems: Concentrations, effects and risk assessment. Env. Int., 84:115-30. 
Frye, C.A., Bo, E., Calamandrei, G., Calza, L., Dessi-Fulgheri, F., Fernandez, M., Fusani, L., Kah, O., Kajta, M., Le Page, Y., Patisaul, H.B., Venerosi, A., Wojtowicz, A.K., Panzica, G.C., 2012. Endocrine disrupters: a review of some sources, effects, and mechanisms of actions on behaviour and neuroendocrine systems. J. Neuroendocrinol., 24, 144-159.

Garcia-Becerra, R., Borja-Cacho, E., Cooney, A.J., Smith, C.L., Lemus, A.E., Perez-Palacios, G., Larrea, F., 2006. Synthetic 19-nortestosterone derivatives as estrogen receptor alpha subtype-selective ligands induce similar receptor conformational changes and steroid receptor coactivator recruitment than natural estrogens. J. Steroid Biochem. Mol. Biol. 99, $108-114$.

Graham, J.D. and Clarke, C.L., 2011. Physiological Action of Progesterone in Target Tissues. Endocr. Rev. DOI: http://dx.doi.org/10.1210/edrv.18.4.0308

Han, J., Wang, Q., Wang, X., Li, Y., Wen, S., Liu, S., Ying, G., Guo, Y., Zhou, B., 2014. The synthetic progestin megestrol acetate adversely affects zebrafish reproduction. Aquat. Toxicol 150, 66-72.

Hanna RN, Daly SC, Pang Y, Anglade I, Kah O, Thomas P, Zhu Y. 2010. Characterization and expression of the nuclear progestin receptor in zebrafish gonads and brain. Biol Reprod. 2010 Jan;82(1):112-22.

Hinfray, N., Tebby, C., Garoche, C., Piccini, B., Bourgine, G., Aït-Aïssa, S., Kah, O., Pakdel, F., Brion, F. (in revision).Additive effects of levonorgestrel and ethynilestradiol on brain aromatase (cyp19a1b) in zebrafish specific in vitro and in vivo bioassays. Tox. Appl. Pharmacol.

Kidd KA, Blanchfield PJ, Mills KH, Palace VP, Evans RE, Lazorchak JM, Flick RW., 2007. Collapse of a fish population after exposure to a synthetic estrogen.Proc Natl Acad Sci U S A.;104(21):8897-901.

Kiyokage, E., Toida, K., Suzuki-Yamamoto, T., Ishimura, K., 2005. Localization of 5alphareductase in the rat main olfactory bulb. J. Comp. Neurol., 493, 381-395.

Kloosterboer, H.J., 2004. Tissue-selectivity: the mechanism of action of tibolone. Maturitas 48 Suppl 1, S30-40.

Kumar, V., Johnson, A.C., Trubiroha, A., Tumova, J., Ihara, M., Grabic, R., Kloas, W., Tanaka, H., Kroupova, H.K., 2015. The challenge presented by progestins in ecotoxicological research: a critical review. Environ. Sci. Technol., 49, 2625-2638. 
Labadie, P., Budzinski, H., 2005. Development of an analytical procedure for determination of selected estrogens and progestagens in water samples. Anal. Bioanal. Chem. 381, 11991205.

Lam, C.S., Marz, M., Strahle, U., 2009. gfap and nestin reporter lines reveal characteristics of neural progenitors in the adult zebrafish brain. Dev. Dyn., 238, 475-486.

Le Page, Y., Diotel, N., Vaillant, C., Pellegrini, E., Anglade, I., Merot, Y., Kah, O., 2010. Aromatase, brain sexualization and plasticity: the fish paradigm. Eur. J. Neurosci. 32, 21052115.

Le Page, Y., Menuet, A., Kah, O., Pakdel, F., 2008. Characterization of a cis-acting element involved in cell-specific expression of the zebrafish brain aromatase gene. Mol. Reprod. Dev., 75, 1549-1557.

Le Page, Y., Scholze, M., Kah, O., Pakdel, F., 2006. Assessment of xenoestrogens using three distinct estrogen receptors and the zebrafish brain aromatase gene in a highly responsive glial cell system. Environ. Health Persp. 114, 752-758.

Lee, M.R., Loux-Turner, J.R., Oliveira, K., 2015. Evaluation of the 5alpha-reductase inhibitor finasteride on reproduction and gonadal development in medaka, Oryzias latipes. Gen. Comp. Endocrinol. 216, 64-76.

Lemmen, J.G., van den Brink, C.E., Legler, J., van der Saag, P.T., van der Burg, B., 2002. Detection of oestrogenic activity of steroids present during mammalian gestation using oestrogen receptor alpha- and oestrogen receptor beta-specific in vitro assays. J. Endocrinol $174,435-446$.

Lemus, A.E., Enriquez, J., Hernandez, A., Santillan, R., Perez-Palacios, G., 2009. Bioconversion of norethisterone, a progesterone receptor agonist into estrogen receptor agonists in osteoblastic cells. J. Endocrinol., 200, 199-206.

Liang, Y.Q., Huang, G.Y., Liu, S.S., Zhao, J.L., Yang, Y.Y., Chen, X.W., Tian, F., Jiang, Y.X., Ying, G.G., 2015. Long-term exposure to environmentally relevant concentrations of progesterone and norgestrel affects sex differentiation in zebrafish (Danio rerio). Aquat. Toxicol 160, 172-179.

Menuet, A., Pellegrini, E., Anglade, I., Blaise, O., Laudet, V., Kah, O., Pakdel, F., 2002. Molecular characterization of three estrogen receptor forms in zebrafish: binding 
characteristics, transactivation properties, and tissue distributions. Biol. Reprod., 66, 18811892.

Menuet, A., Pellegrini, E., Brion, F., Gueguen, M.M., Anglade, I., Pakdel, F., Kah, O., 2005. Expression and estrogen-dependent regulation of the zebrafish brain aromatase gene. J. Comp. Neurol., 485, 304-320.

Mouriec, K., Gueguen, M.M., Manuel, C., Percevault, F., Thieulant, M.L., Pakdel, F., Kah, O., 2009. Androgens upregulate cyp19a1b (aromatase B) gene expression in the brain of zebrafish (Danio rerio) through estrogen receptors. Biol. Reprod., 80, 889-896.

Nash, J.P., Kime, D.E., Van der Ven, L.T., Wester, P.W., Brion, F., Maack, G., StahlschmidtAllner, P., Tyler, C.R., 2004. Long-term exposure to environmental concentrations of the pharmaceutical ethynylestradiol causes reproductive failure in fish. Environ. Health Perspect, 112, 1725-1733.

Orlando, E.F. and Ellstad, L.E. Sources, concentrations, and exposure effects of environmental gestagens on fish and other aquatic wildlife, with an emphasis on reproduction. Gen. Comp. Endocrinol. 203, 241-249 doi:10.1016/j.ygcen.2014.03.038

Overturf, M.D., Overturf, C.L., Carty, D.R., Hala, D., Huggett, D.B., 2014. Levonorgestrel exposure to fathead minnows (Pimephales promelas) alters survival, growth, steroidogenic gene expression and hormone production. Aquat. Toxicol 148, 152-161.

Pasmanik, M., Callard, G.V., 1988. Changes in brain aromatase and 5 alpha-reductase activities correlate significantly with seasonal reproductive cycles in goldfish (Carassius auratus). Endocrinology 122, 1349-1356.

Paulos, P., Runnalls, T.J., Nallani, G., La Point, T., Scott, A.P., Sumpter, J.P., Huggett, D.B., 2010. Reproductive responses in fathead minnow and Japanese medaka following exposure to a synthetic progestin, Norethindrone. Aquat. Toxicol 99, 256-262.

Pellegrini, E., Mouriec, K., Anglade, I., Menuet, A., Le Page, Y., Gueguen, M.M., Marmignon, M.H., Brion, F., Pakdel, F., Kah, O., 2007. Identification of aromatase-positive radial glial cells as progenitor cells in the ventricular layer of the forebrain in zebrafish. J. Comp. Neurol., 501, 150-167.

Runnalls, T.J., Margiotta-Casaluci, L, Kugathas, S, Sumpter, JP 2010. Pharmaceuticals in the Aquatic Environment: Steroids and Anti- Steroids as High Priorities for Research. Human and Ecological Risk Assessment, 16(6): p. 1318-1338. 
Runnalls, T.J., Beresford, N., Losty, E., Scott, A.P., Sumpter, J.P., 2013. Several synthetic progestins with different potencies adversely affect reproduction of fish. Environ. Sci. Technol.,47, 2077-2084.

Safholm, M., Jansson, E., Fick, J., Berg, C., 2015. Mixture effects of levonorgestrel and ethinylestradiol: estrogenic biomarkers and hormone receptor mRNA expression during sexual programming. Aquat. Toxicol 161, 146-153.

Safholm, M., Ribbenstedt, A., Fick, J., Berg, C., 2014. Risks of hormonally active pharmaceuticals to amphibians: a growing concern regarding progestagens. Philosophical transactions of the Royal Society of London. Series B, Biological sciences 369.

Sanchez W, Sremski W, Piccini B, Palluel O, Maillot-Maréchal E, Betoulle S, Jaffal A, AïtAïssa S, Brion F, Thybaud E, Hinfray N, Porcher JM. 2011. Adverse effects in wild fish living downstream from pharmaceutical manufacture discharges. Environ Int., 237(8):13428.

Scott, A.P., Sumpter, J.P., Stacey, N., 2010. The role of the maturation-inducing steroid, 17,20beta-dihydroxypregn-4-en-3-one, in male fishes: a review. J. Fish Biol., 76, 183-224.

Silva, C.P., Otero, M., Esteves, V., 2012. Processes for the elimination of estrogenic steroid hormones from water: a review. Environ. Pollut. 165, 38-58.

Sitruk-Ware, R., 2008. Pharmacological profile of progestins. Maturitas 61, 151-157.

Soffker, M., Tyler, C.R., 2012. Endocrine disrupting chemicals and sexual behaviors in fish-a critical review on effects and possible consequences. Crit. Rev. Toxicol., 42, 653-668.

Strähle U, Scholz S, Geisler R, Greiner P, Hollert H, Rastegar S, Schumacher A, Selderslaghs I, Weiss C, Witters H, Braunbeck T. 2012. Zebrafish embryos as an alternative to animal experiments--a commentary on the definition of the onset of protected life stages in animal welfare regulations. Reprod Toxicol.; 33(2):128-32.

Sumpter, J. P. Endocrine disrupters in the aquatic environment: An overview. Acta Hydrochimica et Hydrobiologica (2005), 33 (1), 9-16 CODEN: AHCBAU; ISSN:03234320. (Wiley-VCH Verlag GmbH \& Co. KGaA)

Sun, L., Jin, R., Peng, Z., Zhou, Q., Qian, H., Fu, Z., 2014. Effects of trilostane and fipronil on the reproductive axis in an early life stage of the Japanese medaka (Oryzias latipes). Ecotoxicology 23, 1044-1054. 
Svensson, J., Fick, J., Brandt, I., Brunstrom, B., 2013. The synthetic progestin levonorgestrel is a potent androgen in the three-spined stickleback (Gasterosteus aculeatus). Environ. Sci. Technol., 47, 2043-2051.

Svensson, J., Fick, J., Brandt, I., Brunstrom, B., 2014. Environmental concentrations of an androgenic progestin disrupts the seasonal breeding cycle in male three-spined stickleback (Gasterosteus aculeatus). Aquat. Toxicol 147, 84-91.

Tong, S.K., Mouriec, K., Kuo, M.W., Pellegrini, E., Gueguen, M.M., Brion, F., Kah, O., Chung, B.C., 2009. A cyp19a1b-gfp (aromatase B) transgenic zebrafish line that expresses GFP in radial glial cells. Genesis 47, 67-73.

Tyler, C.R., Jobling, S., Sumpter, J.P., 1998. Endocrine disruption in wildlife: a critical review of the evidence. Crit. Rev. Toxicol., 28, 319-361.

Van der Linden, SC, Heringa, MB, Man, HY, Sonneveld, E, Puijke,r LM, Brouwer, A, Van der Burg B. 2008 Detection of multiple hormonal activities in wastewater effluents and surface water, using a panel of steroid receptor CALUX bioassays. Environ Sci Technol., 1;42(15):5814-20.

Vosges, M, Le Page Y, Chung BC, Combarnous Y, Porcher JM, Kah O, Brion F. 2010. 17alpha-ethinylestradiol disrupts the ontogeny of the forebrain GnRH system and the expression of brain aromatase during early development of zebrafish. Aquat Toxicol. 15;99(4):479-91.

Zeilinger J1, Steger-Hartmann T, Maser E, Goller S, Vonk R, Länge R. 2009. Effects of synthetic gestagens on fish reproduction. Environ Toxicol Chem., 28(12):2663-70.

Zhao Y, Castiglioni S, Fent K. 2015. Synthetic progestins medroxyprogesterone acetate and dydrogesterone and their binary mixtures adversely affect reproduction and lead to histological and transcriptional alterations in zebrafish (Danio rerio). Environ. Sci. Technol., 7;49(7):4636-45.

Zucchi, S., Castiglioni, S., Fent, K., 2012. Progestins and antiprogestins affect gene expression in early development in zebrafish (Danio rerio) at environmental concentrations. Environ. Sci. Technol 46, 5183-5192.

Zucchi, S., Castiglioni, S., Fent, K., 2013. Progesterone alters global transcription profiles at environmental concentrations in brain and ovary of female zebrafish (Danio rerio). Environ. Sci. Technol 47, 12548-12556. 
Zucchi, S., Mirbahai, L., Castiglioni, S., Fent, K., 2014. Transcriptional and physiological responses induced by binary mixtures of drospirenone and progesterone in zebrafish (Danio rerio). Environ. Sci. Technol 48, 3523-3531.

Zupanc, G.K., 2008. Adult neurogenesis and neuronal regeneration in the brain of teleost fish. J. Physiol, 102, 357-373. 


\section{Figure captions}

Figure 1: In vivo imaging of $4 \mathrm{dpf}$ old live transgenic cyp19a1b-GFP zebrafish embryos exposed to progestins inducing GFP expression in radial glial progenitors. Dorsal views. For each chemical the concentration used is indicated. CTRL: solvent control, H2O: water control, EE2: 17 $\alpha$ ethinylestradiol, RU486: mifepristone, ETH: ethisterone, EDA: ethynodiol diacetate, LYN: lynestrenol, NEA: norethindrone acetate, NET: norethindrone, TIB: tibolone, DSG: desogestrel, ENG: etonogestrel, GES: gestodene, LNG: levonorgestrel, NTE: norgestimate, NGL: norgestrel. tel: telencephalon; poa: preoptic area; nrp: nucleus recessus posterioris of the caudal hypothalamus. Scale bar $=100 \mu \mathrm{m}$.

Figure 2. Luciferase expression after progesterone (P4) treatment. U251-MG cells were transfected with the cyp19a1b-luciferase reporter construct and the expression vector zfER $\alpha(\mathbf{A}), \mathrm{zfER} \beta 1(\mathbf{B})$, or zfERß2 (C). Cells were treated for 24 hours with DMSO (vehicle control), E2 (positive control) and increasing concentrations of P4. Squared boxes show the cyp19a1b-luciferase induction without E2 treatment. Data are expressed as fold induction relative to DMSO (means \pm SEM). Asterisks indicate a significant difference between treatment and vehicle control $(* * * P<0.001)$.

Figure 3. Luciferase fold induction after norethindrone (NET) treatment. U251-MG glial cells were transfected with the cyp19a1b-luciferase reporter construct and the expression vector $\mathrm{zfER} \alpha(\mathbf{A}, \mathbf{D})$, zfER $\beta 1$ (B, E), or zfER $\beta 2$ (C, F). Cells were treated with increasing concentrations of NET (A-C). The estrogen receptor antagonist ICI 182,780 (ICI) was also tested with and without the two highest NET concentrations (D-F). DMSO and E2 were used as vehicle control and positive control (data not shown), respectively. Data are expressed as fold induction relative to DMSO (means \pm SEM). Asterisks indicate a significant difference between treatment and vehicle control, with the exception of those located over the lines representing a significant difference between pointed treatments $\left({ }^{*} P<\right.$ $0.05 ; * * P<0.01 ; * * * P<0.001)$. 
Figure 4. Luciferase fold induction after levonorgestrel (LNG) treatment. U251-MG cells were transfected with the cyp19a1b-luciferase reporter construct and the expression vector $\mathrm{zfER} \alpha(\mathbf{A}, \mathbf{D})$, zfER $\beta 1(\mathbf{B}, \mathbf{E})$, or zfERß2 (C, F). Cells were treated with increasing concentrations of LNG without (A-C) and with ICI 182,780 (ICI) (D-F). DMSO and E2 were used as vehicle control and positive control (data not shown), respectively. Data are expressed as fold induction relative to DMSO (means \pm SEM). Asterisks indicate a significant difference between treatment and vehicle control, with the exception of those located over the lines representing a significant difference between pointed treatments $(* * * P<0.001)$.

Figure 5. Binding properties of NET and LNG with zfERs. zfERs proteins synthetized and biotinylated using Promega's kits (see Material and Methods) and visualized by colorimetric detection method after SDS-PAGE (A). Competition curves after E2, NET and LNG increasing concentrations treatments with constant $\left[{ }^{3} \mathrm{H}\right]-\mathrm{E} 210^{-9} \mathrm{M}$ using zfER $\alpha(\mathbf{B})$, zfER $\beta 1$ (C), or zfER $\beta 2$ (D) synthetized proteins. 


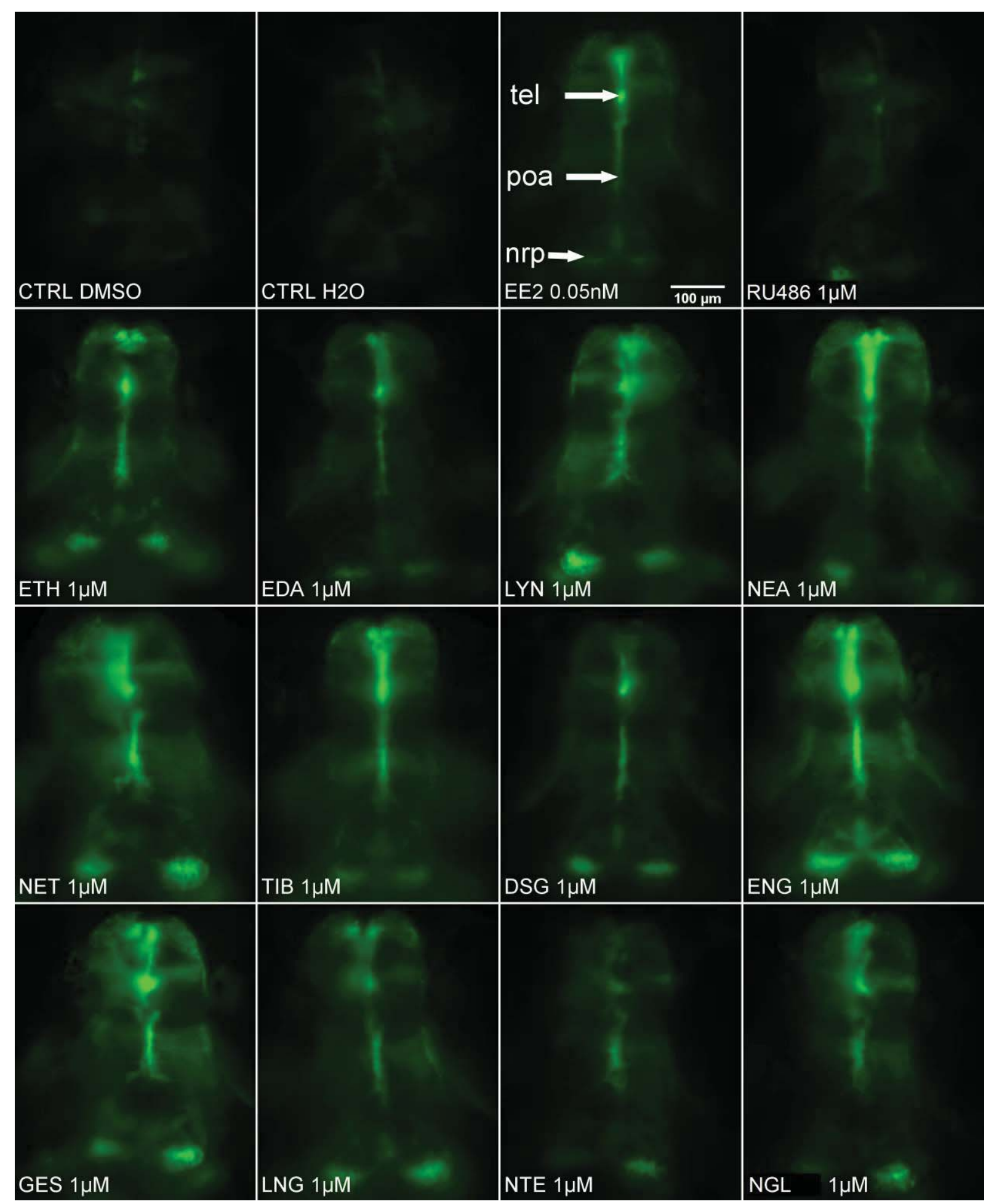

Fig. 1 


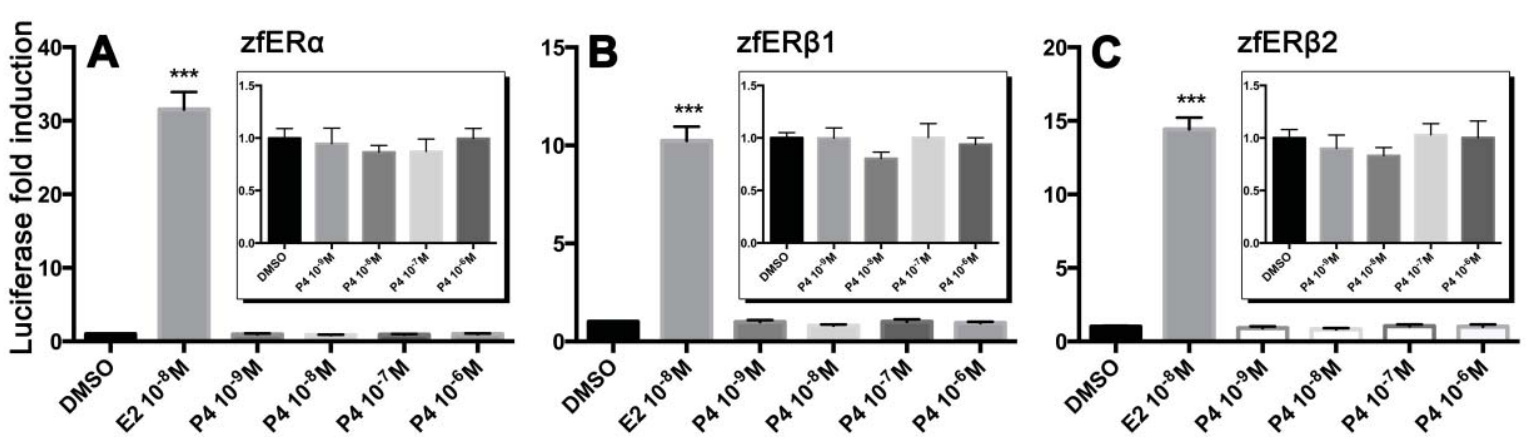

Fig. 2 

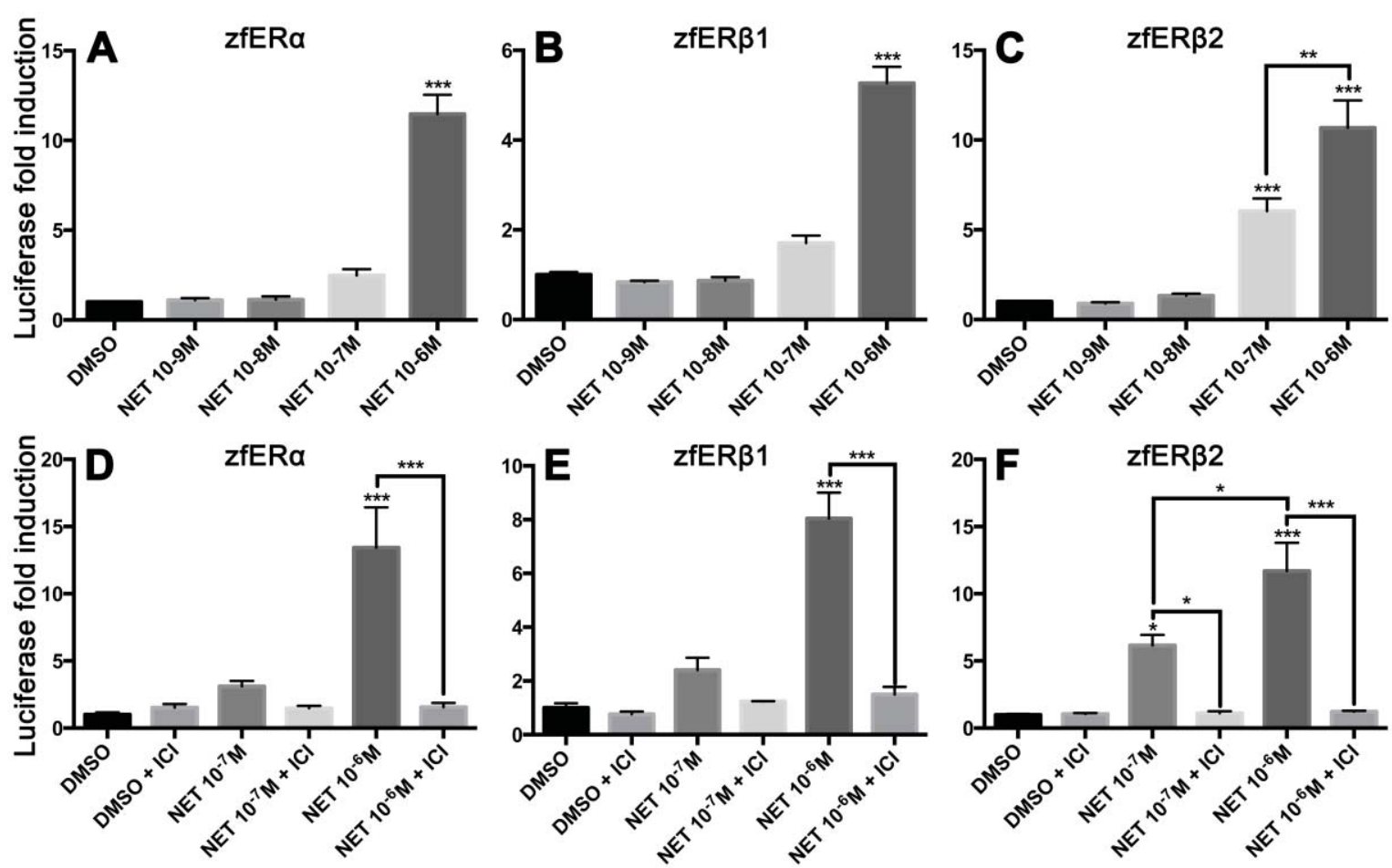

Fig. 3 

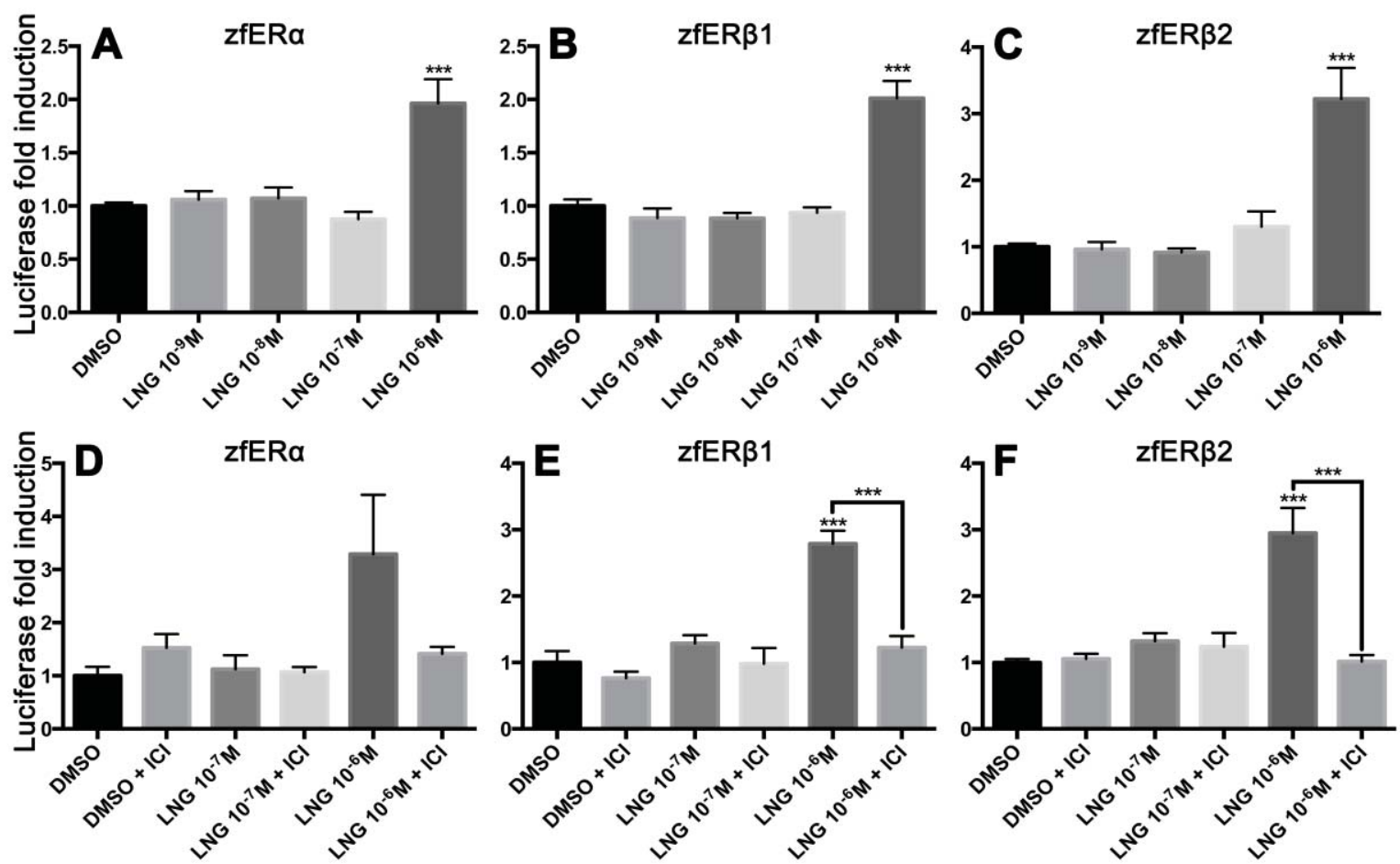

Fig. 4 


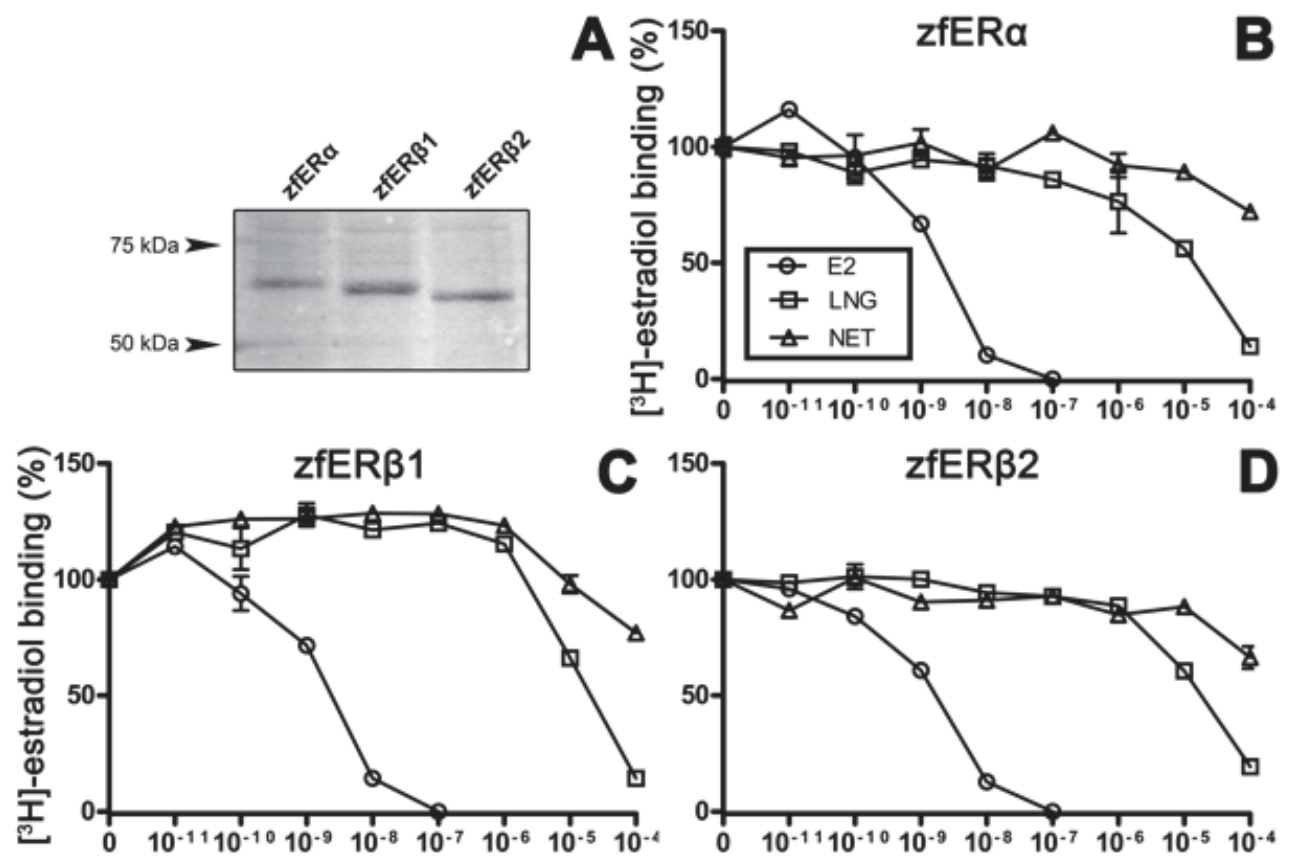

A $\bigodot^{150} 7 \quad$ zfER $\alpha$

B

Fig. 5 
Table 1: Classification of some natural hormones and natural and synthetic nPR ligands.

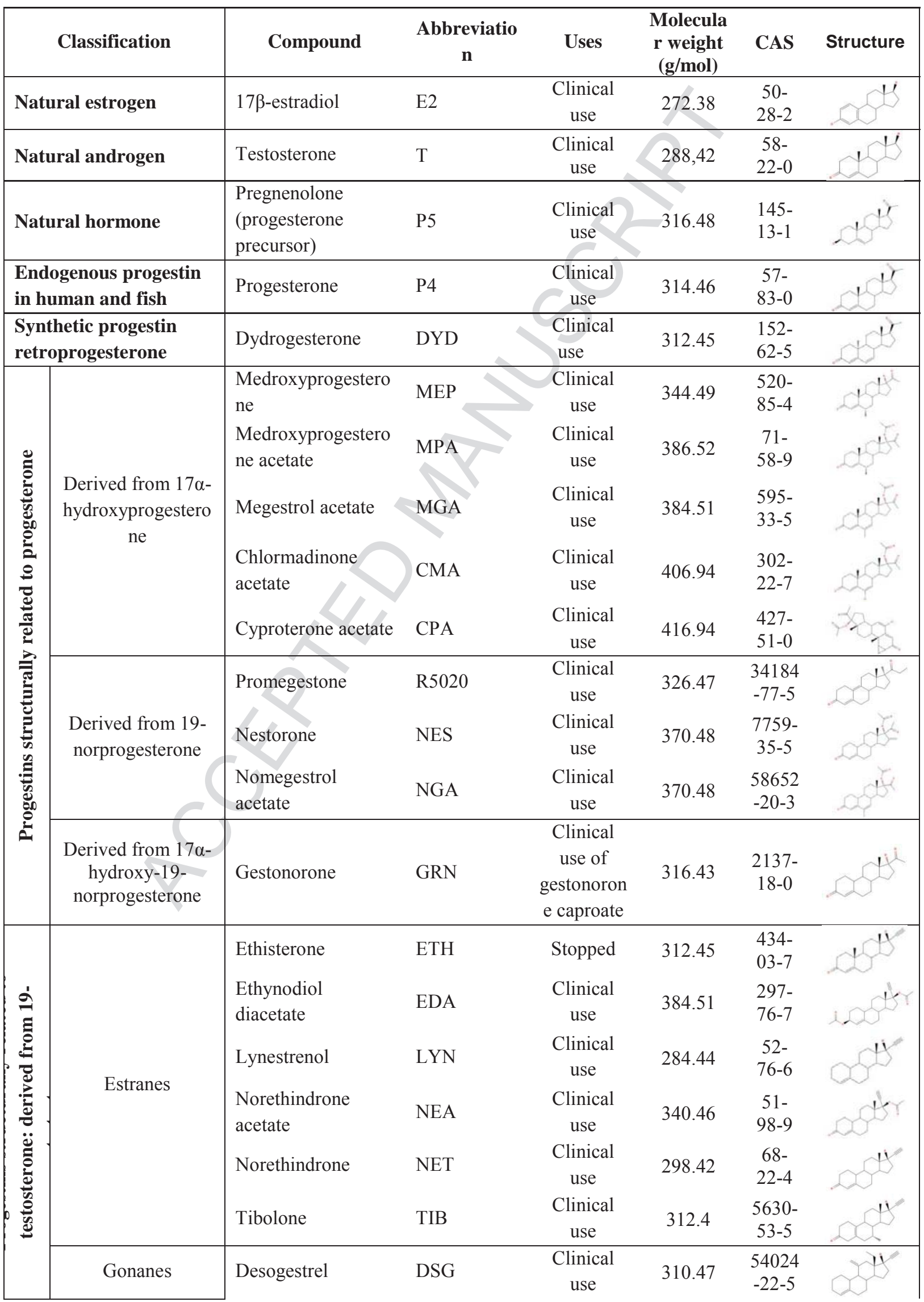




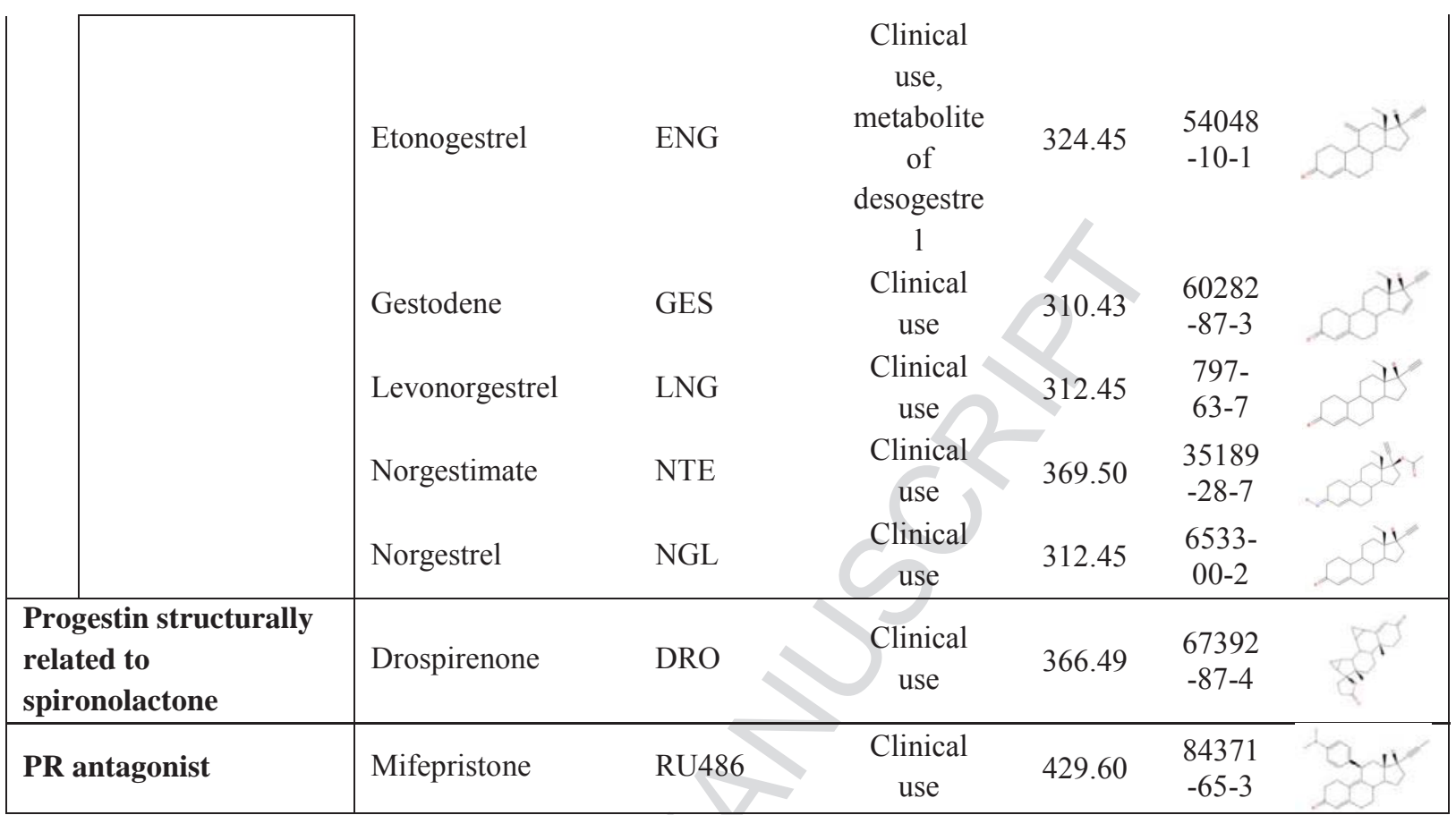


Table 2: Effects of some natural hormones and synthetic progestins on the EASZY assay, calculated effective concentrations $\left(\mathrm{EC}_{20}\right.$ and $\mathrm{EC}_{50}$ expressed in $\left.\mathrm{nM}\right)$ and relative estrogenic potency (REP) for active compounds. +: GFP induction, ne: no effect, nc: not calculated.

\begin{tabular}{|c|c|c|c|c|c|c|c|}
\hline \multicolumn{2}{|c|}{ Classification } & Compound & $\begin{array}{c}\text { Abbrevia } \\
\text { tion }\end{array}$ & $\begin{array}{l}\text { Effect in } \\
\text { EASZY }\end{array}$ & $\begin{array}{l}\mathbf{E C}_{20} \\
(\mathrm{nM}) \\
\end{array}$ & $\begin{array}{l}\mathrm{EC}_{50} \\
(\mathrm{nM})\end{array}$ & REP \\
\hline \multicolumn{2}{|c|}{ Natural estrogen } & $17 \beta$-estradiol & E2 & + & 0.62 & 1.7 & 1 \\
\hline \multicolumn{2}{|c|}{ Natural androgen } & Testosterone & $\mathrm{T}$ & + & 337 & 505 & 0.003 \\
\hline \multicolumn{2}{|c|}{ Natural hormone } & $\begin{array}{l}\text { Pregnenolone } \\
\text { (progesterone } \\
\text { precursor) }\end{array}$ & P5 & + & 105 & 826 & 0.002 \\
\hline \multicolumn{2}{|c|}{$\begin{array}{l}\text { Endogenous progestin in } \\
\text { human and fish }\end{array}$} & Progesterone & P4 & ne & - & - & - \\
\hline \multicolumn{2}{|c|}{$\begin{array}{l}\text { Synthetic progestin } \\
\text { retroprogesterone }\end{array}$} & Dydrogesterone & DYD & ne & - & - & - \\
\hline \multirow{9}{*}{ 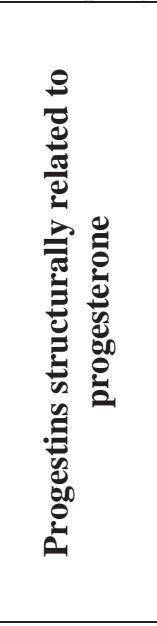 } & \multirow{5}{*}{$\begin{array}{l}\text { Derived from } \\
17 \alpha- \\
\text { hydroxyprogest } \\
\text { erone }\end{array}$} & Medroxyprogesterone & MEP & ne & - & - & - \\
\hline & & $\begin{array}{l}\text { Medroxyprogesterone } \\
\text { acetate }\end{array}$ & MPA & ne & - & - & - \\
\hline & & Megestrol acetate & MGA & ne & - & - & - \\
\hline & & $\begin{array}{l}\text { Chlormadinone } \\
\text { acetate }\end{array}$ & CMA & ne & - & - & - \\
\hline & & Cyproterone acetate & $\mathrm{CPA}$ & ne & - & - & - \\
\hline & \multirow{3}{*}{$\begin{array}{c}\text { Derived from } \\
19- \\
\text { norprogesterone }\end{array}$} & Promegestone & $\mathrm{R} 5020$ & ne & - & - & - \\
\hline & & Nestorone & NES & ne & - & - & - \\
\hline & & Nomegestrol acetate & NGA & ne & - & - & - \\
\hline & $\begin{array}{c}\text { Derived from } \\
17 \alpha-\text { hydroxy- } \\
19- \\
\text { norprogesterone }\end{array}$ & Gestonorone & GRN & ne & - & - & - \\
\hline \multirow{12}{*}{ 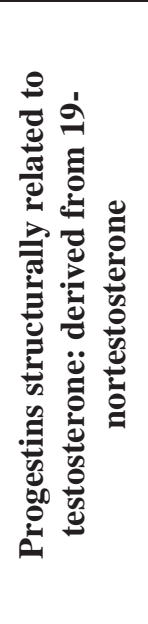 } & \multirow{6}{*}{ Estranes } & Ethisterone & ETH & + & 5.5 & 40 & 0.04 \\
\hline & & Ethynodiol diacetate & EDA & + & 34 & 53 & 0.03 \\
\hline & & Lynestrenol & LYN & + & 3.5 & 16 & 0.1 \\
\hline & & $\begin{array}{l}\text { Norethindrone } \\
\text { acetate }\end{array}$ & NEA & + & 0.4 & 2.4 & 0.7 \\
\hline & & Norethindrone & NET & + & 1 & 4.0 & 0.4 \\
\hline & & Tibolone & TIB & + & 0.1 & 0.3 & 5.7 \\
\hline & \multirow{6}{*}{ Gonanes } & Desogestrel & $\overline{\mathrm{DSG}}$ & $+^{*}$ & nc & nc & $\mathrm{nc}$ \\
\hline & & Etonogestrel & ENG & + & 7 & 39 & 0.04 \\
\hline & & Gestodene & GES & + & 41 & 222 & 0.008 \\
\hline & & Levonorgestrel & LNG & + & 39 & 89 & 0.02 \\
\hline & & Norgestimate & NTE & + & 65 & 126 & 0.01 \\
\hline & & Norgestrel & NGL & + & 73 & 184 & 0.009 \\
\hline \multicolumn{2}{|c|}{$\begin{array}{l}\text { Progestin structurally } \\
\text { related to spironolactone }\end{array}$} & Drospirenone & DRO & ne & - & - & - \\
\hline \multicolumn{2}{|c|}{ PR antagonist } & Mifepristone & RU486 & $+^{*}$ & $\mathrm{nc}$ & $\mathrm{nc}$ & $\mathrm{nc}$ \\
\hline
\end{tabular}

*induction of GFP in tg cyp19a1b-GFP embryos only at $10^{-6} \mathrm{M}$. 


\section{Graphical abstract}

Effect of environmental ligands of progesterone receptor in brain of fish?

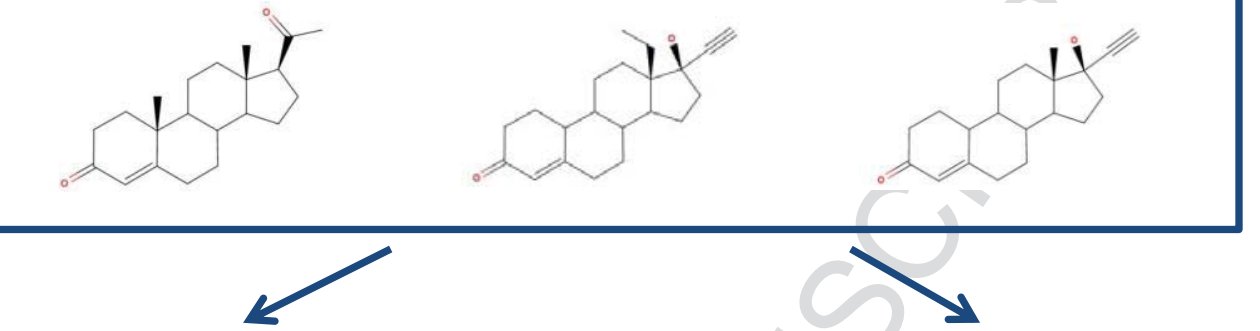

In vivo assay

In vitro assay

cyp19a1b-GFP zebrafish embryos U251 MG cell line (ERs+Cyp19a1b-luc)

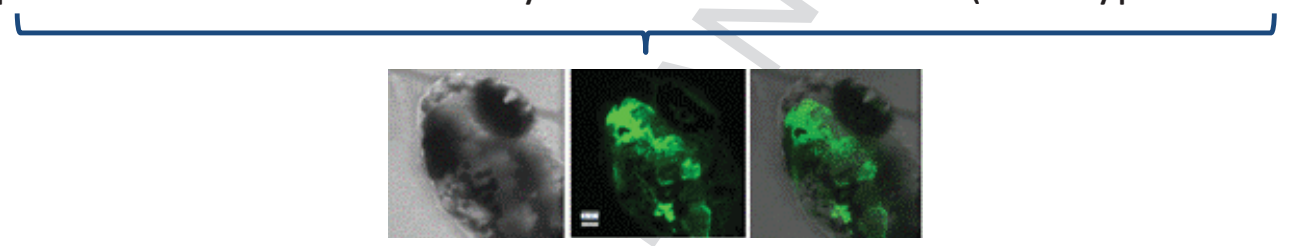

Several progestins induced brain aromatase in vitro and in vivo in radial glial cells 


\section{Highlights}

- P4 + 24 progestins were tested on embryonic brain aromatase expression in zebrafish

- 19 nor-testosterone derivatives induced cyp19a1b expression

- cyp19a1b up-regulation involved functional zfERs

- 19 nor-testosterone derivatives are pro-estrogenic compounds.

- Effect of progestins should be further investigated at the brain level 